\title{
The Case for Incomprehension
}

\author{
Neal Allar
}

Journal of French and Francophone Philosophy - Revue de la philosophie française et de langue française, Vol XXIII, No 1 (2015) pp 43-58.

\author{
Vol XXIII, No 1 (2015) \\ ISSN 1936-6280 (print) \\ ISSN 2155-1162 (online) \\ DOI 10.5195/jffp.2015.680 \\ www.jffp.org
}

\section{(oc) BY-NG-ND}

This work is licensed under a Creative Commons Attribution-Noncommercial-No Derivative Works 3.0 United States License.

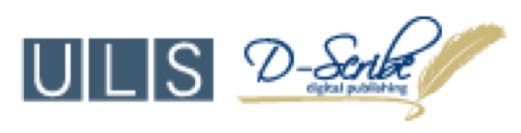

This journal is operated by the University Library System of the University of Pittsburgh as part of its D-Scribe Digital Publishing Program, and is co-sponsored by the University of Pittsburgh Press 


\title{
The Case for Incomprehension Édouard Glissant's Poetics of Relation and the Right to Opacity
}

\author{
Neal Allar \\ Cornell University \\ ...nous voyons les corbeaux et nous disons : ils parlent une \\ langue étrangère... mais non, les corbeaux ne parlent pas une \\ langue étrangère, les corbeaux parlent leur propre langue et \\ nous ne la comprenons pas...
}

- $\quad$ Simone Schwartz-Bart

The Universal Declaration of Human Rights, adopted by the United Nations in 1946, resolves that education should, first of all, develop intercultural understanding: "Education [...] shall promote understanding, tolerance and friendship among all nations, racial or religious groups." ${ }^{\prime 1}$ Understanding, it is supposed, fosters respect for human dignity, connects people across lines of difference, and counters the dehumanizing impulse of genocide and colonialism. A generation later, though, the Martinican poet and philosopher Édouard Glissant would assert a very different human right, namely, the right not to be understood: "Nous réclamons le droit à l'opacité." ${ }_{2}$ Opacité has since become a recognizable term in the multidisciplinary realm of postcolonial theory, as literary critics, anthropologists, historians and sociologists investigate how subjects and cultures maintain their specificity against the universalizing tendencies of globalization and neocolonialism. ${ }^{3}$ A person exercises the right to opacity by refusing to conform to rationalist modes of understanding; he or she resists any epistemology that would "construct the Other as an object of knowledge." In what follows, I argue that Glissant conceived of opacity first and foremost in his poetry and in his readings of earlier writers, from Mallarmé to Saint-John Perse to William Faulkner, whose moments of complication or incomprehensibility he found productive. By examining the literary valence of this concept of Caribbean philosophy, I claim that opacity

Journal of French and Francophone Philosophy | Revue de la philosophie française et de langue française Vol XXIII, No 1 (2015) | www.jffp.org | DOI 10.5195/jffp.2015.680 
not only protects the subject from the invasive grasp of (neo)colonial thought but also, more affirmatively, invites the reader to join the poet on equal footing in the process of sense-making. It is this kind of collective poetics, a collectivity created in opacity, that Glissant imagines in his broader world vision of Relation and the Tout-Monde.

Glissant's vast corpus of poems, novels, theatre and critical essays begins in the late 1940s and ends just before his death in 2011. The notion of opacity gets developed throughout the entirety of this long career, including in the earliest poetry collections Le sang rivé and Un champ d'îles, but Caribbean and postcolonial studies tend to focus on Glissant's assertion of the droit à l'opacité at the beginning of the seminal critical work Le discours antillais (1981). It is here that the term's political, militant valence appears most fully. Opacity becomes a mode of survival for "les peuples néantisés qui opposent aujourd'hui à l'universel de la transparence, imposé par l'Occident." ${ }_{5}$ This call for epistemological resistance has fit well into a postcolonial discourse that emphasizes the subaltern's power to "write back," as Helen Tiffin puts it, not only to a Western audience but also "to the whole of the discursive field" that mediates and hierarchizes the reading of texts. ${ }^{6}$ The right to opacity could be seen as a kind of radical "writing back" that challenges, at the most basic level, the idea of reading comprehension. Additionally, Michael Dash notes that this resistance can take form in the radical cultural impenetrability of the Maroons - the descendants of escaped slaves still living in isolated communities in Caribbean islands' mountainous interior - or as a "more anonymous and pedestrian form of resistance" in everyday language. ${ }^{8}$ Celia Britton provides a compelling account of the political stakes of this militancy:

Relation and opacity work together to resist the reductiveness of humanism [...] In this sense opacity becomes a militant position [...] opacity is also a defense against understanding, at least in the hierarchical, objectifying way in which this usually operates between the West and the Third World [...] The right to opacity [...] is a right not to be understood.

Glissant's etymological critique of "comprehension" as a possessive seizure (com-prehendere) confirms Britton's sense that opacity applies to both the subject and his or her speech. More recently, in the 2013 issue of Callaloo dedicated to Glissant soon after his death, H. Adlai Murdoch describes how this mode of resistance fits, ontologically and epistemologically, into the philosophy of the Tout-Monde that Glissant develops in his later work: "Opacité, then, serves to posit an unknowable otherness that, in its turn, mediates a new groundwork for being-in-the-world. At bottom, it is an epistemologically-grounded world vision that allows each subject the right to her or his own unknowability." ${ }^{10}$ For Murdoch, moreover, opacity is a cultural phenomenon as much as an individual one: "Such an interpretation of opacity inscribes an implicit recognition that each subject maintains

Journal of French and Francophone Philosophy | Revue de la philosophie française et de langue française Vol XXIII, No 1 (2015) | http://www.jffp.org | DOI 10.5195/jffp.2015.680 
cultural patterns and artifacts that will remain incomprehensible to other subjects who are not inscribed in, or have not been formed by, the same culture." "The upshot of Murdoch's argument is, quite crucially, that the category of opacity must necessarily arise from a situation of colonial domination, in which one group requires this form of epistemological resistance in order to preserve its subjective agency, in order to survive as a culture. In the postcolonial global age, the right to opacity would mediate the relationship between the local and the global by guaranteeing cultural specificity against the homogenizing forces of neoliberal economics and dominant cultural trends.

However, these accounts' inattention to the poetic, that is, creative or productive power of opacity reflects the simplification that the term has undergone in discussions of Glissant's oeuvre. Few scholars remember how Glissant develops opacity in the work of the 1950s and 1960s, including the poems in Un champ d'îles and Le sang rivé and the essays in Soleil de la conscience and L'intention poétique. Opacity, especially at that time, was tied deeply to Glissant's experience of reading and writing literature. The eventual militancy of the claim to the right to opacity grew out of Glissant's experience of language as the medium through which all political activity must occur. To read the right to opacity as a poetic claim as much as a political one is not to reduce its political purchase, nor to exaggerate poetry's importance to specific political action. Rather, it is to recognize the fundamental importance of poetry to the vision of human interaction that Glissant calls Relation, whose activity he calls, quite deliberately, the "poetics" of Relation. It is to reintroduce complexity into a term that, despite its critique of reductive understandings, has itself been reduced to a simple understanding. Opacity, in its fullest sense, provides not simply a protective shield for the postcolonial subject but rather an affirmative modality for reading, writing and interacting in the postcolonial world. In the same way, Glissant's poetry, some of the most opaque work written in French in the twentieth century, does not seek to preserve local cultural artifacts from the influence of outside forces; on the contrary, it entrusts itself to the world, embracing, as Glissant repeatedly affirms, the unforeseeable (imprévisible) possibilities of the enunciation.

Opacity is Relation's epistemology and poetic modality. It conditions the apprehension of knowledge and the experience of self-expression in a system of thought opposed to the colonial order. Glissant spends his entire career conceptualizing Relation, and opacity remains closely tied to Relation throughout its development. Glissant's thought, then, rests on a chief paradox: a notion of intercultural and inter-subjective relationality that depends, strangely, on incomprehension. His championing of opacity in his 
later essays (after 1980), I will argue, occurs as a tacit rereading of the poetic works and the literary criticism he published earlier in his career. As he shifts between and mixes philosophical frameworks and methodologies throughout his essays, Glissant continually renews his reflection on the potential for poetic language to create Relation precisely by remaining dense, difficult or opaque. I will thus highlight how opacity's development as a poetic concept was implicated in the development of Glissant's philosophical thought, particularly the different ontological and epistemological concepts that inform his articulation of Relation across his career.

The shifts in Glissant's thought have been much debated in recent years. Peter Hallward's polemical Absolutely Postcolonial challenges the widely held notion that Glissant's oeuvre is a long elaboration of a set of key concepts and that "his major preoccupations are apparent from the earliest writing." Hallward argues instead that the "late Glissant" (after the publication of Le discours antillais in 1981) shifts radically away from specific political concerns of national liberation towards an over-aestheticized, apolitical poetics. In Hallward's critique, this shift is symptomatic of postcolonial studies in general, which, under the influence of such theorists as Homi Bhabha and Gayatri Chakravorty Spivak and the postmodern philosophy of Gilles Deleuze and Félix Guattari, has moved away from an examination of "specific" anti-colonial action, toward celebrations of abstract, generalized "singularity." Nick Nesbitt and Chris Bongie, though more generous towards Glissant, also identify an "aesthetic turn" in the later work. ${ }^{\text {. Celia }}$ Britton and Charles Forsdick, on the other hand, have argued that this shift does not signify a turn away from politics but rather a different way of approaching the set of political questions with which Glissant has always been concerned." My interest in this debate lies in how it has largely located Glissant's "shift" in his adoption of Deleuze in Poétique de la Relation and, moreover, the assertion (by Nesbitt and Hallward in particular) of Glissant's latent Hegelianism earlier in his career. Although I ultimately argue that Glissant's poems and poetic prose disrupt this periodization - it is quite Deleuzian before Deleuze even wrote his first book - Glissant's mixing and moving between the seemingly disparate philosophical frameworks of Hegel and Deleuze fundamentally inform his conceptualization of opacity throughout his essays.

It is strange to speak of a Hegelian Glissant, for, as Glissant himself points out, Hegel's racism and Eurocentrism is stark.15 Nonetheless, Nick Nesbitt's work in Voicing Memory successfully demonstrates the degree to which Glissant's notion of Relation is in fact a "dialectical relation" - a system built upon the interaction of opposing terms. Alexandre Kojève's revival of Hegel in the 1930s and 1940s, indeed, had a great influence on Glissant's predecessors in the Negritude movement, as did the dialectical thought of Jean-Paul Sartre. As Nesbitt argues, Hegel provided the anti- 
colonial Negritude movement with both a language of resistance, which Sartre famously summed up in his phrase "anti-racist racism," and a hope that by negating the colonized self in their writing, the Negritude poets could enter into history as liberated subjects. ${ }^{16}$ Arriving at the tail-end of this movement, Glissant sought to imagine dialectical resistance as an affirmative mode of expression. From the beginning of L'intention poétique (1969), opacity becomes an integral condition for the concept of relation, ${ }^{17}$ and the influence of Hegelian dialectics looms large. The negation of comprehension by opacity, the tension between the self's desire to understand and the other's densité or impenetrability, gives way to a higher mode of self-expression: "la poétique de la relation suppose qu'à chacun soit proposée la densité (l'opacité) de l'autre. Plus l'autre résiste dans son épaisseur ou sa fluidité (sans s'y limiter), plus sa réalité devient expressive, et plus la relation féconde." ${ }^{18}$ Relation here occurs as a dialectical synthesis between the drive to understand and the opacity that resists this understanding; the greater the tension that this resistance creates, the richer the experience of relation that follows.

Even a cursory glance at Glissant's early musings shows that this dialectic movement pervades Glissant's world. Soleil de la conscience (1956) is the first volume in the essay series called "Poétiques" that spans Glissant's career and renders his philosophical notions into a distinctly poetic language. In its more imagistic moments, Soleil, like Glissant's early poetry, is full of contrasts between light and dark, ethereal and dense, fluid and solid, opaque and transparent. Speaking of his preference for working in the hours before dawn, the young Glissant reveals his taste for such opposites:

J'ai peur de hâter cette nuit. D'épuiser déjà cette nuit où l'obscurité monte comme un amour défunt. Je m'obstine à cette ultime clarté d'avant le matin: elle est sauvage et drue, quelque splendeur qui de soi-même s'affame. ${ }^{19}$

The "ultimate clarity" occurs in the dark, in the petit matin, recalling Aimé Césaire's famous refrain in Cahier d'un retour au pays natal. This clarity is, oddly, "drue" - one of Glissant's favorite adjectives at this stage in his career, uniting the sense of vigor and proliferation with a feeling of impenetrable density, like a thick plant. The word is prominent in the poetry collection $U n$ champ d'îles, published four years earlier, where it is also associated with the contrast between night and day, clarity and obscurity:

Mais lui ne touche plus que les bâtisses de ce bruit autour des rues où l'herbe pousse. Elle pousse ! drue et sanglante dans son cœur (est-ce la rue, ou bien son cœur ?) - drue et blessée, l'herbe a gravi la nuit! Maintenant sur la prairie les beaux pluviers réapparus font des réverbères, non, des étoiles. Qu'est-ce l'étoile sinon la chose très obscure $[\ldots] ?^{20}$

Journal of French and Francophone Philosophy | Revue de la philosophie française et de langue française Vol XXIII, No 1 (2015) | http://www.jffp.org | DOI 10.5195/jffp.2015.680 
On the one hand, drue, which refers most literally to a plant whose multiple stems result in a dense mass, foreshadows Glissant's later adoption of Deleuze's ontology of proliferating multiplicity, the rhizome. On the other hand, drue is inscribed into these passages' play of productive contradictions: clarity can only come about via an engagement with obscurity ("Qu'est-ce l'étoile sinon la chose très obscure"), and darkness provides the ground for the "splendeur" of Glissantian poetics.

Just as the adjective dru both expresses the dialectical movement of Glissant's early writing and hints at his future adoption of Deleuzian nomadology, so does the explicit mention of dialectics in Soleil de la conscience coincide with a language of chaos that presages Glissant's much later category of the chaos-monde. Indeed, it is only in retrospect that these two systems might seem separate, for in Glissant's paragraphs the "synthesis" of cultures in the Antilles occurs in a state of productive chaos. Of the Antilles, Glissant affirms, "voici une synthèse de races, de mœurs, de savoirs, mais qui tend vers son unité propre." ${ }_{21}$ This "unity," though, is always in question due to the disorganizing forces of Antillean multiplicity, as he asserts only a page later. Here, Glissant's challenge to the postcolonial world is to embrace this synthetic chaos as a poetics that inevitably reverberates into politics: "il est un temps d'ouverture chaotique, de pressentiment anarchique de l'histoire, de mâchage furieux des mots, de saisi vertigineuse des clartés." ${ }_{22}$ Indeed, throughout his oeuvre, Glissant attempts to bring the powerful push-pull movement of binary opposites (opacity and transparency not the least of them) into a system that also recognizes complex, nonlinear, nonhierarchical proliferation as an affirmative challenge to old colonial hierarchies and rationalist epistemologies. The later works on Relation and Tout-Monde attempt more formally to theorize this progression toward the Whole, the Tout, that nonetheless cannot be expressed as a comprehensive singularity but rather as an incomprehensible mass of proliferating offshoots.

The early poetry enacts this paradoxical system by demonstrating a fascination with dialectical opposites while also, with its ambiguous pronouns and paratactic combinations of diverse images, lending itself to an "ouverture chaotique." Indeed, the great number of dialectical opposites do not resolve into neat syntheses but rather propel the expression into a space of deliberate disorder, for the collision of such elements as light and dark or fluid and solid calls into question the very epistemology that separated them in the first place. In the following passage from Un champ d'îles, for example, the "moi" encapsulates qualities of impenetrability and density and, at the same time, radical transparency and permeability - a celebration of the oxymoron's ability to disrupt the compartmentalizing tendency of conventional language:

Les fleuves passent à travers moi vers la transparence des terres me voilà $[\ldots]$

Journal of French and Francophone Philosophy | Revue de la philosophie française et de langue française Vol XXIII, No 1 (2015) | http://www.jffp.org | DOI 10.5195/jffp.2015.680 
Dans ce foisonnement de soleils que distribuent l'arrosoir des arbres C'est moi la rivière la roche impassible et dans son sein l'ardeur de la terre

La foudre la main qui caresse l'éclair la main qui offre c'est nous $[\ldots]^{23}$

The contrast between the flowing transparency of the river and the hard impassibility of the boulder is reflected in the tension between the unpunctuated, fluid syntax and the impenetrable collection of words which do not cohere into a comprehensive message. Similar meditations, both formal and conceptual, on the tension between these contrasting perceptions of the world crop up throughout Glissant's early literature. This literature's distinctive opacity, its resistance to easy comprehension or explication, reinforces the sense that the most productive and enlightening vision of the world arises from experiences of abysmal darkness. Similarly, the wisdom of the Caribbean, as he later says in "La barque ouverte," is derived from the collective memory of the "expérience du gouffre" - the bowels of the slave ship, the graveyard of the Atlantic. ${ }^{24}$

Whereas the poetic writing, including parts of Soleil de la conscience as well as the first two collections of poetry, complicates this dialectic relationality with a proto-Deleuzian movement of chaotic proliferation, Glissant's earlier literary criticism bears more exclusively the signs of Hegelian influence. Glissant's first formal analysis of opacity comes in L'intention poétique. The chapter entitled "Sur l'opacité" is an examination of William Faulkner's novels, especially Absalom, Absalom! Glissant asserts, in an overt dialectic, that Faulkner's failure to enter into his black characters' psyches is, in fact, one of the most positive elements of his examination of racial politics in the American South. The Black American, in this fiction, can only be known by his opacity, which renders his character all the more expressive:

L'opacité du Nègre pour Faulkner est, bien entendu, son impénétrabilité : autant que la peau noire, l'âme obscure [...] Le monologue intérieur ne sera jamais propre au personnage noir, et ce qu'on surprendra le plus souvent de celui-ci ce sera un grommellement $[\ldots]$ Pourquoi donc ces personnages $[\ldots]$ nous retiennent-ils? Précisément pour leur négativité révélatrice : pour l'impossibilité où se trouve l'auteur, qui les a créés, d'aller au fond de leurs motivations. Ils opposent ainsi à Faulkner lui-même un non au-delà qu'il ne franchira jamais. Autrement dit: l'incapacité de Faulkner à cerner ce personnage est positive.2.

Faulkner brings his black characters to life precisely by laying bear his own inability to gain access to their inner life. ${ }^{26}$ It is not simply a question of respecting the other's impenetrability or irreducibility. In this dialectical logic, incomprehensibility becomes a positive, a "négativité révélatrice," in

Journal of French and Francophone Philosophy | Revue de la philosophie française et de langue française Vol XXIII, No 1 (2015) | http://www.jffp.org | DOI 10.5195/jffp.2015.680 
which the character's opacity signals an overcoming of the reader's reductive grasp and, moreover, a new way of understanding that relies on a self-conscious critique of the literary and linguistic processes through which knowledge is apprehended. A different version of this logic appears in the prose poetry of Un champ d'îles, which contains the paradoxical refrain, "Absente qui êtes présence!" ${ }_{28}$ In the context of a Caribbean history defined by the decimation of native populations and the violent uprooting of African populations from their ancestral homes, presence cannot come about without a prior absence. Caribbean knowledge depends upon a confrontation with the obscurity at the heart of its narrative, and Glissant seems to suggest that Caribbean poetics must carry the mark of that obscurity - must acknowledge the contingency or incompleteness of all knowledge. He finds a similar gesture in Faulkner's fiction, which casts a veil over a tragic secret at its core - in Absalom, Absalom!, this secret is the miscegenation in the Sutpen family - and the act of reading leads to an avowal of that secret without the complete comprehension of it. The entire narration of Absalom, Absalom! is indeed a series of unreliable rereadings by various characters. Layers of storytelling disrupt the access to the original historical facts of the Sutpen family tragedy. The novel thus critiques the possibility of storytelling itself as a form of unveiling, and the object of examination becomes, rather than the truth behind the fiction, the mechanism itself of this necessarily opaque fiction:

Affirmer en même temps le secret original et exposer un mécanisme de son dévoilement, c'est aviver la conscience collective, l'entretenir dans l'angoisse et l'interrogation. Le roman dévoile un voilé qui ne devient jamais pur dévoilé mais s'expose dans la mécanique même du dévoilement. ${ }^{20}$

The dizzying oscillations of what Glissant calls "cette suprême dialectique" reenacts the collective "vertige" that he claims Faulkner's novels elicit in their readers, a vertigo rooted in the American historical memory, which relies on an idea of racial and ancestral purity but which is constantly confronted by the fact of métissage or miscegenation at its secret center. America was built on a foundation of racial mixing, but its dominant narrative constantly struggles to recuperate its pure "roots" in the Old World. Faulkner's opaque writing avows this uncomfortable fact precisely by examining the veil that has been cast over the métissage at the origins of American history. The motivations of such characters as Charles Bon and Joe Christmas, both of whom "pass" as white until their blackness is discovered, provide the core mystery around which Faulkner's complex and difficult sentences turn. ${ }^{30}$

After L'intention poétique, Glissant's next work of critical prose is the seminal Discours antillais, in which he first asserts the "droit à l'opacité." The Discours probably remains Glissant's most canonical text, ${ }^{31}$ and it also speaks most clearly to the specific issues of the departmentalization of the French

Journal of French and Francophone Philosophy | Revue de la philosophie française et de langue française Vol XXIII, No 1 (2015) | http://www.jffp.org | DOI 10.5195/jffp.2015.680 
West Indies. It mentions opacity in the first pages and, later, in its discussion of Martinican Creole, which began, Glissant claims, as a willful inscrutability vis-à-vis the white plantation families. It is in the Discours that opacity takes on its most militant valence - "l'élan des peoples néantisés qui opposent aujourd'hui à l'universel de la transparence, imposé par l'Occident" ${ }^{\prime 2}$ - but, crucially, Glissant also critiques Martinican Creole (as opposed to Haitian Creole) for its insularity, which he calls a "poétique contrainte," because it fails to adapt itself to the needs of a free population and autonomous economy. ${ }^{33}$ The failures of Creole, Glissant asserts, are closely tied to Martinique's economic failures: an island that no longer produces its own goods must import everything it needs; its own language therefore cannot be the language of the marketplace. ${ }^{34}$ It is beyond the scope of this essay to analyze the complex demands that Glissant makes of his island, but suffice it to say that an enclosed, protective form of opacity was never the solution. Even in Le discours antillais, opacity's resistant function retains the dialectic impulse to project expression outward, to turn a form of resistance into a mode of sharing, to open itself via its initial closure. The debate in Martinique between Creole and French, he states, must end in the affirmation of an opacity that is constantly active, constantly renewing its process and diversifying itself:

D’abord, du point de vue du débat entre ces deux langues, le créole et le français, dont l'une a jusqu'ici subi la transcendance de l'autre, on peut affirmer que la seule pratique possible est de les rendre opaques l'une à l'autre. Développer partout, contre un humanisme universalisant et réducteur, la théorie des opacités particulières. Dans le monde de la Relation, qui prend le relais du système unifiant de l'Être, consentir à l'opacité c'est-à-dire la densité irréductible de l'autre, $c^{\prime}$ est accomplir véritablement, à travers le divers, l'humain. L'humain n'est peut-être pas l'«image de l'homme » mais aujourd'hui la trame sans cesse recommencée de ces opacités consenties..$^{35}$

It would be simple enough to read this paragraph as positing a pure opposition, in which French and Creole form opposing terms - "opaque, l'une à l'autre" - imagining opacity as a mechanism for relation via mutual self-distinction. However, elements of the Glissant of Poétique de la Relationthe first text after the so-called "aesthetic turn" in Glissant's career - are already present in the Discours's account of opacity, in its insistence on a solidarity built in opacity. The language here refers tacitly to the notion of text: etymologically speaking, "la trame" - the weave - creates the text (from the Latin textus, "thing woven"). The notion of "opacité consenties," in addition to calling for a mutual acceptance of incomprehension, carries the implication of a broader, collective sense-making (con-sentir).

Journal of French and Francophone Philosophy | Revue de la philosophie française et de langue française Vol XXIII, No 1 (2015) | http://www.jffp.org | DOI 10.5195/jffp.2015.680 
This may seem like etymological quibbling if it were not for the fact that Glissant increases this textual/textile lexicon in his later work. In his chapter in Poétique de la Relation entitled "Pour l'opacité," Glissant uses the metaphor of the text as a "weave" to argue that opacity occurs not in isolation but rather in open solidarity. For him, coexistence is precisely what distinguishes "difference" from "opacity." The textual metaphor is much more explicit here than in the Discours, and in the spirit of Glissantian poétique, it assumes the fundamental connection between the socio-political and the literary:

Non pas seulement consentir au droit à la différence mais, plus avant, au droit à l'opacité, qui n'est pas l'enfermement dans une autarcie impénétrable, mais la subsistance dans une singularité non réductible. Des opacités peuvent coexister, confluer, tramant des tissus dont la véritable compréhension porteraient sur la texture de cette trame et non pas sur la nature des composants. ${ }^{36}$

Glissant here conceives of opacity as a textual weave that must be created by collectivities. The refusal to penetrate to the "nature" of the text speaks quite directly to the material image of an opaque text, whose incomprehensibility disrupts the penetration to a "deeper meaning" and rather draws the attention to its corporeal surface, its "texture." Opacity achieves this horizontal, collective signification as part of the quasi-Deleuzian system that Glissant imagines in Poétique de la Relation, which borrows from Deleuze such terms as the Baroque, the rhizome, and the chaos-monde (from Deleuze's chaosmos, in turn borrowed from Joyce) to contest what he calls the rationalist idea of "Nature [...] harmonieuse, homogène et connaissable en profondeur." ${ }_{37}$ Glissant heralds the Baroque as a recognition of the world's chaotic, ever-changing, unpredictable existence - in short, a challenge to the rationalistic mindset that laid the groundwork for colonialism and human objectification. Drawing on Deleuze's analysis of art, architecture and philosophy in Le pli, Glissant asserts that Baroque art provided a challenge to the predominant, essentializing epistemology in Europe:

L'art baroque fut une réaction contre la prétention rationaliste à pénétrer d'un mouvement uniforme et décisif les arcanes du connu. Le frisson baroque vise à signifier par là que toute connaissance est à venir, et que c'est ce qui en fait la valeur. Aussi bien les techniques du baroque vont-elles favoriser $l^{\prime}$ « extension» au lieu de la «profondeur $» .^{38}$

If Relation is the dynamic world vision that comes of this Baroque aesthetic, then opacity is its form of expression. The opaque text, such as Glissant encountered in his readings of Mallarmé, Saint-John Perse and Faulkner, refuses a poetics of depth and forces a reading of the surface. The collective reading of the surface, in which meaning is not fixed or determined but rather unpredictable and constantly renewed with every

Journal of French and Francophone Philosophy | Revue de la philosophie française et de langue française Vol XXIII, No 1 (2015) | http://www.jffp.org | DOI 10.5195/jffp.2015.680 
reading, stands in stark contrast to the Erasmian humanist ideal of a single scholar penetrating to the original, underlying truth of a text. ${ }^{30}$ The political stakes of such a reading are considerable; the embrace of unknowability not only resists the impulse to subsume subjects into racial or cultural essences but, more affirmatively, provides a modality for producing meaning in a way that recognizes the infinite possibility of the opaque text. A text that cannot be mastered can thus be understood in a multiplicity of ways. This is not to collapse signification into a nihilistic form of moral relativism; it is indeed a kind of relativism inasmuch as it places meaning in relation with other possibilities of meaning which could have been realized under other circumstances, but it is not the kind of relativism in which a subject appropriates meaning for his own use. As Deleuze explains in Le pli, a baroque relativism demonstrates to the reader or viewer that a variation in meaning had always been possible: “Ce n'est pas une variation de la vérité d'après le sujet, mais la condition sous laquelle apparaît au sujet la vérité d'une variation." " "The surface reading, the reading of opacity in Relation, includes a consciousness of the collective, multiple activity in which each reading must take part.

Glissant thus increasingly adopts the terms of Deleuze's immanent ontology (even if the earlier texts developed similar ideas with less distinct terms), in which being is a single material plane extending to infinity, as opposed to the separation between material and transcendental, divine or ideal realms. Poétique de la Relation explains Relation as rhizomatic, borrowing the key term from Deleuze's work with Félix Guattari in Mille plateaux. As opposed to the "arborescent" system of the root, in which knowledge returns to an idealized, unified and recognizable origin, the rhizome is a stem without a root, an inherently multiple growth proliferating in all directions: "un rhizome ne commence et n'aboutit pas, il est toujours au milieu, entre les choses, inter-être, intermezzo." ${ }^{\prime 1}$ Yet whereas Deleuze and Guattari conceive of the rhizome as wholly different from a binary, Hegelian root system ("un rhizome comme tige souterraine se distingue absolument des racines et radicelles"), ${ }^{42}$ Glissant maintains the language of the root, conceiving of the rhizome as a multiplied root: "La racine est unique, c'est une souche qui prend tout sur elle et tue alentour ; [Deleuze et Guattari] lui opposent le rhizome qui est une racine démultipliée, étendue en réseau dans la terre ou dans l'air, sans qu'aucune souche y intervienne en prédateur irrémédiable." ${ }^{\star 3}$ Glissant's misreading of Deleuze and Guattari here demonstrates his commitment to finding an alternative root system for the Caribbean subject, whom the slave trade and plantation system violently deracinated. Excluded from Western, capital-H Histoire, Glissant says, the Caribbean subject must accede to, via a poetic act, a multiplicity of "histoires"; Deleuze and Guattari, on the other hand, firmly oppose any kind of "histoire," which implies a rooted sequence. ${ }^{45}$

Journal of French and Francophone Philosophy | Revue de la philosophie française et de langue française Vol XXIII, No 1 (2015) | http://www.jffp.org | DOI 10.5195/jffp.2015.680 
Thus, despite his enthusiasm for Deleuze's affirmative and proliferating ontology, Glissant maintains the Hegelian privilege of the entry into history: "Of course, Glissant criticizes the erasure of Antillean difference within the putative universalism of classical and late French colonialism, but he does so within the horizon of a greater totality: that of a self-conscious, globally engaged subject." ${ }_{46}$ The making of "histoires" as opposed to "Histoire" constitutes the Caribbean form of this becoming-self-conscious. Similarly, if the late version of Relation follows the Deleuzian modality of the rhizome, it still depends upon the Hegelian language of the Other (which Deleuze carefully avoids): "La pensée du rhizome serait au principe de ce que j'appelle une poétique de la Relation, selon laquelle toute identité s'étend dans un rapport à l'Autre." It would be hard to find a more economical coupling of Deleuze and Hegel, a mixing of ontologies of immanent extension and dialectic relation - a coupling unwilled by Deleuze. ${ }^{48}$ Nesbitt is thus right to propose that Glissant's work is "divided, somewhat schizophrenically, [...] between a Spinozian [and, implicitly, Deleuzian] discourse of unbroken immanence and one of dialectical enlightenment." Considering Deleuze's and Guattari's adoption of "schizo-analyse" as an alternative to the arborescent, Oedipal discourse of psychoanalysis, Nesbitt's term tacitly suggests that Glissant is more Deleuzoguattarian than Deleuze and Guattari themselves, that is, more willing to bring together disparate concepts in a single system of thought.

Opacity accordingly bears the mark of this schizophrenic ontology. On the one hand, the material presence of incomprehensible language causes sense to ramify extensively and affirmatively rather than to be found through the penetration to a rooted referent. On the other hand, the opaque surface both negates access to a deeper meaning and provides a new form of visibility, namely, the text's material presence. Hallward, in his sharp critique of Glissant, claims that this new visibility becomes yet another mode of counterproductive reduction, a new transparency: "Glissant's famous defence of the 'right to opacity,' then, must be understood [...] as a mechanism organized in the interest of its own eventual dissolution [...] The specifically opaque will itself become the means to a more total becomingtransparent which surpasses it and includes it." ${ }_{\mathrm{so}_{0}}$ Hallward's rote rehearsal of the Hegelian dialectic, in which every term contains the seeds of its own selfannihilation, is valid inasmuch as it refers to a greater form of understanding that opacity brings about. Glissant even appears to make such a claim, renewing transparence as a positive term in a few places in his work, in sharp contrast to the far more numerous moments when he decries transparency as an invasive, essentializing rationalism. In Poétique de la Relation, for example, he uses transparence to describe the free movement of Relation made possible by the work of opacity:

Nous appelons donc opacité ce qui protège le Divers. Et désormais nous appelons transparence l'imaginaire de la Relation, qui en

Journal of French and Francophone Philosophy | Revue de la philosophie française et de langue française Vol XXIII, No 1 (2015) | http://www.jffp.org | DOI 10.5195/jffp.2015.680 
pressentait depuis longtemps (depuis les Présocratiques? Depuis les Mayas? Dans Tombouctou déjà? Depuis les poètes préislamiques et les conteurs indiens ?) les tourbillons imprévisibles. ${ }^{51}$

In this case, though, in which transparence takes on a surprisingly affirmative valence, we must be willing to hear transparence not as grasping, comprehending or peering through - transparency - but rather of "transpearance," the horizontal movement of presences and meanings in the system of Relation. Opacité produces transparence not by generating a new fixed and apprehensible object of meaning but rather by motivating the multiple emergence of meanings across a broad spectrum. Such a system of sense-making - a collective, multivalent, horizontal poetics - creates the conditions for the kind of interpersonal and intercultural activity that Glissant envisions in Relation.

Glissant's poetics in general and his notion of opacity in particular do not tend towards a conclusion, inasmuch as this word implies "closure." I have argued that a text's or a subject's opacity does a great deal more than close off points of access; it opens an alternative space of meaning, in which the reader, interlocutor or audience must participate in meaning-making, all the while recognizing the necessary incompleteness of this creative act. Opacity, then, leaves us with a strong sense of inconclusiveness, an uncertainty that only increases as the experience of the text becomes more powerful. Glissant says as much in the introductory prose-poem of Le sang rivé - the very first page of his Poèmes complets. Both stylistically and conceptually, he prepares his reader for a dynamic but fragmented, scattered expression that requires collective reassembly, a reassembly that guarantees that the poem will not seek the static perfection of being but rather channel the dynamic energy of endless becoming, "sans cesse devient":

Non pas l'œuvre tendue, sourde, monotone autant que la mer qu'on sculpte sans fin - mais des éclats, accordés à l'effervescence de la terre[...] - toujours demis, toujours repris, et hors d'achèvement - [...]

These unfinished bursts, he continues, lead to a kind of perfection through their own imperfection and to true knowledge via an embrace of the uncertain. The dialectical ear perks up at this play of opposites, but a protoDeleuzian sensibility also charges the volcanic power of Glissant's scattered, comprehension-resistant mode of expression:

Premiers cris, rumeurs naïves, formes laissées - témoins, incommodes pourtant, de ce projet - qui, de se rencontrer imparfaits se trouvent solitaires parfaitement - et peuvent ici convaincre de s'arrêter à l'incertain - cela qui tremble, vacille et sans cesse devient - comme une terre qu'on ravage - épars.

Journal of French and Francophone Philosophy | Revue de la philosophie française et de langue française Vol XXIII, No 1 (2015) | http://www.jffp.org | DOI 10.5195/jffp.2015.680 
The ambiguous pronouns and accumulating relative clauses - a common feature in Glissant's poetry - testify to his admiration for Faulkner and Mallarmé. However, whereas these two modernist writers both dramatize their own anxiety about the uncertainty inherent in their expression, Glissant affirms this uncertainty as the crucial quality of his poetics. This affirmation points to the productive quality of opacity, the ability for opacity to ramify senses and meanings out into a collective space. Thus, rather than expressing anxiety about an inaccessible "deeper" meaning concealed beneath the surface of the text, Glissant emphasizes the material text itself: "non des cuvres mais la matière elle-même dans quoi l'ouvrage chemine." As the verb cheminer implies, Glissant's text can have the feeling of an extended, winding exploration - an always unfinished survey of a vast geography. Glissant's writing is itself, in a sense, as "uncertain" as the reader's own experience of the opaque text. The writing is opaque to itself; it does not know where it is going, for it relies on its readers for propulsion. Conversely, as a reader assumes a role in the text's creation, in its poetics, she must realize that she is turning but one thread in the vast weave of this totalité-monde of Glissant's poem. Incomprehensible because too vast to sum up and too dynamic to capture, the opaque work is the textual model of a poetics of Relation: collectively wrought and utterly unmasterable. ${ }^{52}$

1 “The Universal Declaration of Human Rights," The United Nations, accessed May 11, 2015, http://www.un.org/en/documents/udhr/, 26.2.

2 Édouard Glissant, Le discours antillais (Paris: Gallimard, 1997), 14.

3 J. Michael Dash, Édouard Glissant (Cambridge: Cambridge University Press, 1995), 1.

${ }^{4}$ Celia Britton, Édouard Glissant and Postcolonial Theory: Strategies of Language and Resistance (Charlottesville: University Press of Virginia, 1999), 19.

${ }^{5}$ Glissant, Le discours antillais, 14

6 Helen Tiffin, "Post-colonial Literatures and Counter-Discourse," in The Postcolonial Studies Reader, ed. Bill Ashcroft, Gareth Griffiths and Helen Tiffin (London: Routledge, 1995), 98.

${ }^{7}$ Dash, Édouard Glissant, 137.

${ }^{8}$ Ibid., 156.

${ }^{9}$ Britton, Édouard Glissant and Postcolonial Theory, 19.

${ }^{10} \mathrm{H}$. Adlai Murdoch, “Édouard Glissant's Creolized World Vision: From Resistance and Relation to Opacité," Callaloo 36, no. 4 (2013): 885.

11 Ibid.

${ }^{12}$ Dash, Édouard Glissant, 27. 
${ }^{13}$ Nick Nesbitt, “Early Glissant: From the Destitution of the Political to Antillean Ultra-Leftism," Callaloo 36, no. 4 (2013): 934. Chris Bongie, Friends and Enemies: The Scribal Politics of Post/colonial Literature (Liverpool: Liverpool University Press, 2008), 328-329.

${ }^{14}$ Celia Britton, “Philosophy, Poetics, Politics,” Callaloo 36, no. 4 (2013): 846. Charles Forsdick, “Late Glissant: History, 'World Literature,' and the Persistence of the Political, Small Axe 14, no. 333 (2010): 124.

${ }^{15}$ In the Philosophy of History, Hegel famously relegates the African peoples to the a-historical and the Native American peoples to the prehistorical, giving them no part of the subject-defining Weltgeist. See The Philosophy of History, trans. J. Sibree (Mineola, NY: Dover, 1956), 99. Glissant comments upon this in Le discours antillais, 227.

16 Nick Nesbitt, Voicing Memory: History and Subjectivity in French Caribbean Literature, (Charlottesville: University Press of Virginia, 2003), 25.

${ }^{17}$ Glissant only begins capitalizing the $\mathrm{R}$ in Relation in the next book of essays, Le discours antillais, more and more imagining the concept as, in Celia Britton's words, "a system rather than as a number of separate singular relations. It is, however, a fluid and unsystematic system whose elements are engaged in a radically nonhierarchical free play of interrelatedness" (11). The "relation" of L'intention poétique already speaks to this interrelatedness, but it is not yet an independent ontological system.

${ }^{18}$ Édouard Glissant, L'intention poétique (Paris: Seuil, 1969), 23.

${ }^{19}$ Édouard Glissant, Soleil de la conscience (Paris: Falaize, 1956), 14.

${ }^{20}$ Édouard Glissant, Poèmes complets (Paris: Gallimard, 1994), 69, my italics.

${ }^{21}$ Glissant, Soleil de la conscience, 15

22 Ibid., 16.

${ }^{23}$ Glissant, Poèmes complets, 25.

${ }^{24}$ Édouard Glissant, Poétique de la Relation (Paris: Gallimard, 1990), 20.

${ }^{25}$ Glissant, L'intention poétique, 176-177.

${ }^{26}$ A notable exception to this rule occurs in "The Fire and the Hearth," the long second story in Go Down, Moses. Lucas Beauchamp, son of the slaves Tennie and Tomey's Turl is the main character. An extra-diegetic and apparently reliable narrator gives the reader access to Beauchamp's interiority. Glissant does indeed mention Beauchamp in Poetics of Relation, speaking about this very issue, but he refers to a different novel in which Beauchamp is also a character: "Ainsi encore, le personnage noir Lucas, qui est pourtant le héros principal de L'intrus, n'est jamais par Faulkner intériorisé, il est décrit tout en postures et en gestes, une silhouette qui se parfait sur un horizon" (Poétique de la Relation, 80). Glissant's eloquent description aptly describes the treatment of Lucas Beauchamp in Intruder in the Dust, but he neglects to mention that Faulkner's reader has already gained a measure of access to Beauchamp in the earlier story.

${ }^{27}$ In his Science of Logic Hegel argues that, in the dialectical method, negation is paradoxically the condition for any affirmative: "Negation is just as much Affirmation as Negation." See G. W. F. Hegel, Science of Logic, vol. 1, trans. W. H. Johnston and L. G. Struthers (London: Allen and Unwin, 1929), 65.

${ }^{28}$ Glissant, Poèmes complets, 60.

Journal of French and Francophone Philosophy | Revue de la philosophie française et de langue française Vol XXIII, No 1 (2015) | http://www.jffp.org | DOI 10.5195/jffp.2015.680 
${ }^{29}$ Glissant, L'intention poétique, 178.

${ }^{30}$ Glissant's chapter on opacity in L'intention poétique focuses primarily on Charles Bon in Absalom! Absalom! His more recent work, including Faulkner, Mississippi, has also addressed the question of métissage in Faulkner's Light in August, with the character of Joe Christmas. For a thorough analysis of the latter, see Valérie Loichot's chapter "William Faulkner's Crossroads: Light in August" in her book Orphan Narratives: The Postplantation Literature of Faulkner, Glissant, Morrison, and Saint-John Perse (Charlottesville: University of Virginia Press, 2007), 117-156.

${ }^{31}$ The Discours's canonicity in the U.S. appears to be confirmed by its prominence on reading lists for M.A. and Ph.D. qualifying examinations. Given Glissant's resistance to conventional, filial regimes of knowledge, we must recognize the problem with inscribing him into such a tradition. The fact that most scholars' idea of Glissantian opacity comes exclusively from the Discours, however, suggests that the canon has indeed taken a toll on Glissant's work despite its anticanonical thrust.

${ }^{32}$ Glissant, Le discours antillais, 14.

33 Ibid., 402-403.

${ }^{34}$ Ibid., 410-411.

35 Ibid., 418.

${ }^{36}$ Glissant, Poétique de la Relation, 204.

${ }^{37}$ Ibid., 91.

${ }^{38}$ Ibid., 91-92.

39 Umberto Eco, in The Open Work, also connects the Baroque to a participatory poetics; see Umberto Eco, The Open Work, trans. Anna Cancogni (Cambridge: Harvard UP, 1989), 7. Similarly, Roland Barthes's analysis of Baroque literature in Le Bruissement de la langue bears a striking resemblance to Glissant's notion of opacity: “démontrant ainsi que cette vitre n'existe pas, qu'il n'y a rien à voir derrière le langage, et que la parole loin d'être l'attribut final est la dernière touche de la statue humaine, comme le dit le mythe trompeur de Pygmalion, n'en est jamais que l'étendue irréductible"; see Roland Barthes, Le Bruissement de la langue (Paris: Seuil, 1984), 267. Like Deleuze, moreover, both of these thinkers connect Baroque signification to the open poetics of Mallarmé.

${ }^{40}$ Gilles Deleuze, Le pli : Leibniz et le Baroque (Paris: Minuit, 1988), 27.

${ }^{41}$ Gilles Deleuze, Mille plateaux (Paris: Minuit, 1980), 36.

42 Ibid., 13

${ }^{43}$ Glissant, Poétique de la Relation, 23, my italics.

${ }^{44}$ Glissant, Le discours antillais, 227.

${ }^{45}$ Deleuze, Mille plateaux, 34.

${ }^{46}$ Nesbitt, Voicing Memory, 181.

${ }^{47}$ Glissant, Poétique de la Relation, 23.

${ }^{48}$ Deleuze's Différence et répétition makes his most explicit critique of Hegel's dialectic negation, proposing instead a progression by affirmation: “L'histoire ne passe pas par la négation, et la 
58 The Case for Incomprehension

négation de la négation, mais par la décision des problèmes et l'affirmation des différences. Elle n'en est pas moins sanglante et cruelle pour cela"; see Différence et répétition (Paris: Presses Universitaires de France, 1968), 344.

${ }^{49}$ Nesbitt, Voicing Memory, 189.

${ }^{50}$ Peter Hallward, Absolutely Postcolonial: Writing between the Singular and the Specific (Manchester: Manchester University Press, 2001), 78.

${ }^{51}$ Glissant, Poétique de la Relation, 75.

52 I would like to thank Laurent Dubreuil for providing support and inspiration for my research on opacity. This essay also benefited from comments and encouragement by Natalie Melas, Gerard Aching and Antoine Traisnel. Additionally, I am grateful to Jan Steyn for his feedback on an earlier draft, and to Nick Nesbitt and Diane Brown for their advice in the essay's final stages.

Journal of French and Francophone Philosophy | Revue de la philosophie française et de langue française Vol XXIII, No 1 (2015) | http://www.jffp.org | DOI 10.5195/jffp.2015.680 